Sains Malaysiana 49(12)(2020): 2997-3005

http://dx.doi.org/10.17576/jsm-2020-4912-11

\title{
Enhanced Performance of Quantum Dots Sensitized Solar Cell Utilizing Copper Indium Sulfide and Reduced-Graphene Oxide with the Presence of Silver Sulfide
} (Peningkatan Prestasi Sel Suria Dipekakan Titik Kuantum menggunakan Tembaga Indium Sulfida dan Grafin Oksida Terturun dengan Kehadiran Perak Sulfida)

\author{
Nurul Syafiqah Mohamed Mustakim, Muhazri Abd Mutalib, Suhaila Sepeai, Norasikin Ahmad \\ LUDIN, MOHD ASRI MAT TERIDI \& MOHD ADIB IBRAHIM*
}

\begin{abstract}
In this study, $\mathrm{rGO} / \mathrm{CuIn} \mathrm{S}_{2}$ has been successfully prepared onto $\mathrm{TiO}_{2}$ thin film using solvothermal method followed by $\mathrm{Ag}_{2} \mathrm{~S}$ deposition layer by successive ionic layer adsorption and reaction deposition (SILAR) technique. The morphology, structural, and optical properties of $\mathrm{TiO}_{2} / \mathrm{rGO} / \mathrm{CuInS} \mathrm{S}_{2}$ thin film were investigated by using field emission scanning electron microscopy (FESEM), energy-dispersive X-ray spectroscopy (EDX), atomic force microscope (AFM), X-ray diffraction (XRD) and ultra-violet-visible near infrared spectrophotometer (UV-Vis). For electrical properties, electrochemical impedance spectra (EIS) and current-voltage (I-V) test investigated the interfacial charge-transfer resistances and the conversion efficiency of the samples. Results showed that the average particles size of the samples ranged from \pm 46.52 to $\pm 53.97 \mathrm{~nm}$ in diameter. UV-VIS analysis indicated that $\mathrm{TiO} / \mathrm{rGO} / \mathrm{CuInS}$, thin film showed better light absorption capability with the presence of $\mathrm{Ag}_{2} \mathrm{~S}$ deposition layers. The $\mathrm{rGO} / \mathrm{CuInS}$, quantum dot sensitized with $\mathrm{Ag}_{2} \mathrm{~S}$ layers exhibit a photovoltaic power conversion efficiency of $0.33 \%$, which has great improvement of short circuit current $\left(\mathrm{I}_{\mathrm{SC}}\right)$ comparing with that of $\mathrm{rGO} / \mathrm{CuInS} \mathrm{S}_{2}$ quantum dot sensitized without $\mathrm{Ag}_{2} \mathrm{~S}$ deposition layers.
\end{abstract}

Keywords: $\mathrm{Ag}_{2} \mathrm{~S}$; $\mathrm{CuInS}_{2}$; quantum dots; rGO; SILAR; solar cells; solvothermal

\section{ABSTRAK}

Dalam kajian ini, rGO/CuInS, telah berjaya disediakan ke atas filem nipis $\mathrm{TiO}_{2}$ dengan menggunakan kaedah solvoterma diikuti dengan lapisan pemendapan $\mathrm{Ag}_{2} \mathrm{~S}$ melalui teknik penjerapan dan tindak balas lapisan ion berturutturut (SILAR). Sifat morfologi, struktur dan optik bagi filem nipis $\mathrm{TiO}_{2} / \mathrm{rGO} / \mathrm{CuInS} \mathrm{S}_{2}$ dikaji dengan menggunakan mikroskopi elektron imbasan bidang (FESEM), spektroskopi sinar-X penyebaran tenaga (EDX), mikroskop kekuatan atom (AFM), difraksi sinar-X (XRD) dan spektrofotometer dekat inframerah ultraungu boleh nampak (UV-VIS). Untuk sifat elektrik, ujian elektrokimia impedansi spektra (EIS) dan arus-voltan (I-V) mengkaji rintangan pemindahan cas antara muka dan kecekapan penukaran sampel. Hasil kajian menunjukkan bahawa ukuran purata bagi sampel hablur adalah berkisar antara \pm 46.52 hingga $\pm 53.97 \mathrm{~nm}$. Analisis UV-VIS menunjukkan bahawa filem nipis TiOz $r G O / C u I n S_{2}$ menunjukkan keupayaan penyerapan cahaya yang lebih baik dengan adanya lapisan pemendapan $\mathrm{Ag}_{2} \mathrm{~S}$. Titik kuantum terpeka $\mathrm{rGO} / \mathrm{CuInS} \mathrm{S}_{2}$ dengan lapisan $\mathrm{Ag}_{2} \mathrm{~S}$ menunjukkan kecekapan penukaran kuasa fotovoltan sebanyak $0.33 \%$, yang mempunyai peningkatan arus litar pintas $\left(\mathrm{I}_{\mathrm{SC}}\right)$ yang besar berbanding dengan titik kuantum terpeka rGO/ CuInS 2 tanpa lapisan pemendapan $\mathrm{Ag}_{2} \mathrm{~S}$.

Kata kunci: $\mathrm{Ag}_{2} \mathrm{~S}$; $\mathrm{CuInS}_{2}$; rGO; sel suria; SILAR; solvoterma; titik kuantum

\section{INTRODUCTION}

The range of materials and structures of solar cells is very important to achieve good photovoltaic devices (Kouhnavard et al. 2014). Due to its extra-ordinary properties, graphene shows promising applications in many fields such as photovoltaic devices, nano- electrochemical systems, nanoelectronics, and mechanical alloying (Ubani et al. 2016; Zhang et al. 2015a). Basically, graphene is a mono-layer structure of two-dimensional graphite which makes it an ideal material to has the ability as a larger donor-accepter interface with quantum dots (QDs) material. Besides, since the work function 
of this semi metallic graphene is $4.5 \mathrm{eV}$, it is capable of dissociating excitons that generated in the QDs (Kumari et al. 2014). It is highly transparent as well as able to absorbs $2.3 \%$ of incident white light which making it highly suitable for photo anode applications in solar cell devices (Madhavan et al. 2012). According to Kumari et al. (2014), the presence of graphene in photovoltaic applications are likely to produce better stability of the devices.

The application of $\mathrm{CuInS}_{2}$ QDs in photovoltaic application have already been studied due to its unique properties such as non-toxicity material and high absorption coefficient. There are various synthesis methods including solid state reaction, hot injection method, chemical bath deposition, solvothermal and SILAR technique have been applied to prepare $\mathrm{CuInS}_{2}$ nanostructures (Hosseinpour-Mashkani et al. 2014, Mustakim et al. 2018). However, the power conversion efficiency the current CuInS, based QDSSCs is still low and not satisfactory for practical application to be commercialized.

On the other hand, introduction of passivation layer in QDSSCs has been proved can help to enhance the performance of solar cells (Peng et al. 2014). Thin layer that passivate the QDs could improve QDs stability and promote electron injection from the QDs to the photo anode. It can also prevent leakage of current from the QDs to electrolyte, which can enhance the performance of QDSSCs. According to Holi et al. (2017), $\mathrm{Ag}_{2} \mathrm{~S}$ is one of the best materials to be used in solar cells since it is environmentally benign material. In addition, $\mathrm{Ag}_{2} \mathrm{~S}$ has a large absorption coefficient and a direct band gap of 0.9 to $1.05 \mathrm{eV}$ which is equal to the optimal band gap of $1.13 \mathrm{eV}$ for a photovoltaic device (Tubtimtae et al. 2010).

Therefore, the aim of this study was to investigate the performance of the $\mathrm{CuInS}_{2}$ quantum dot and $\mathrm{rGO}$ with and without the presence of $\mathrm{Ag}_{2} \mathrm{~S}$ as interface layer on the QDSSCs. The morphology, structural, optical, and electrical properties of nanostructured $\mathrm{CuInS}_{2}$ QDs and the rGO as an effective photosensitizer and the presence of $\mathrm{Ag}_{2} \mathrm{~S}$ layers in solar cell were carried out during the investigation. From this study, the optimum performance of environment friendly $\mathrm{TiO}_{2} / \mathrm{rGO} / \mathrm{CuInS}_{2} / \mathrm{Ag}_{2} \mathrm{~S}$ thin films can be applicable as a photoanode for QDSSCs.

\section{MATERIALs AND Methods}

\section{MATERIALS}

All reagents including hydrochloride acid $(\mathrm{HCl}, 36.5 \%$ - 38\%; J.T. Baker), titanium chloride $\left(\mathrm{TiCl}_{4}, 99 \%\right.$; Merck), graphene oxide (rGO) powder, cupric acetate monohydrate $\left(\mathrm{Cu}(\mathrm{Ac})_{2} \cdot \mathrm{H}_{2} \mathrm{O}, 99 \%\right.$; Merck), indium acetate (In (Ac) 3 , 99.99\%; Sigma Aldrich), octadecylamine (90\%;
Merck), thiourea (CS $\left(\mathrm{NH}_{2}\right)_{2}, 99 \%$; Sigma Aldrich), silver nitride $\left(\mathrm{AgNO}_{3}, 99.8 \%\right.$; R\&M Chemicals), sodium sulfide ( $\mathrm{Na}_{2} \mathrm{~S}$, Sigma Aldrich), absolute ethanol, and methanol.

\section{EXPERIMENTAL PROCEDURES}

$\mathrm{TiO}_{2}$ nanoparticles has been synthesized onto cleaned FTO glass using modified hydrothermal method by Han et al. (2015). The $15 \mathrm{~mL}$ of deionized (DI) water was mixed with $15 \mathrm{~mL}$ of $\mathrm{HCl}$. The mixture was stirred for 5 min followed by $0.5 \mathrm{~mL} \mathrm{TiCl}_{4}$. The mixture was stirred for another $5 \mathrm{~min}$ and then placed in a Teflon-lined stainlesssteel autoclave. Then, one piece of FTO substrate was placed at an angle against the wall of the Teflon liner with the conductive side facing down. A reaction temperature of $180{ }^{\circ} \mathrm{C}$ was used for $10 \mathrm{~h}$ reaction time. After synthesis, the autoclave was cooled down to room temperature. Then the FTO substrate was rinsed extensively with DI water and allowed to dry in ambient air. Lastly, annealed at $450{ }^{\circ} \mathrm{C}$ for $30 \mathrm{~min}$.

The $\mathrm{rGO} / \mathrm{CuInS}_{2}$ QDs was prepared using modified solvothermal method by Yue et al. (2014). Firstly, $2.5 \mathrm{mg}$ of rGO powder was dispersed in $50 \mathrm{~mL}$ absolute ethanol by ultrasonication to obtain a homogeneous suspension. Then, $0.05 \mathrm{mmol}$ of $\mathrm{Cu}(\mathrm{Ac})_{2}$. $\mathrm{H}_{2} \mathrm{O}$ was dispersed followed by additional of $\operatorname{In}(\mathrm{Ac})_{3}(0.05 \mathrm{mmol})$ into the dispersion. $0.60 \mathrm{mmol}$ of octadecylamine was ultrasonically dissolved into the dispersion. Next, $0.2 \mathrm{mmol} \mathrm{CS}\left(\mathrm{NH}_{2}\right)_{2}$ was added and a dark-coloured dispersion was produced which also known as $\mathrm{CuInS}_{2}$ precursor. The $\mathrm{CuInS}_{2}$ precursor was then transferred into a Teflon-lined stainless-steel autoclave with $\mathrm{TiO}_{2}$ thin film that placed at an angle against the wall of the Teflon liner with the conductive side facing down. The autoclave was heated at $160{ }^{\circ} \mathrm{C}$ for $8 \mathrm{~h}$ reaction time. After the autoclave naturally cooled to room temperature, the product was collected by centrifugation $(10,000 \mathrm{rpm}$, $8 \mathrm{~min}$ ), washed several times with absolute ethanol and dried under $\mathrm{N}_{2}$ at $60^{\circ} \mathrm{C}$ for $3 \mathrm{~h}$.

A modified SILAR technique by Zhang et al. (2015b) was used to deposit $\mathrm{Ag}_{2} \mathrm{~S}$ layer onto $\mathrm{TiO}_{2} / \mathrm{rGO} /$ $\mathrm{CuInS}_{2}$ thin film. Briefly, $\mathrm{TiO}_{2} / \mathrm{rGO} / \mathrm{CuInS}_{2}$ thin film was dipped into $\mathrm{AgNO}_{3}$ ethanol solution for $3 \mathrm{~min}$, then rinsed with ethanol. Next, $\mathrm{TiO}_{2} / \mathrm{rGO} / \mathrm{CuInS}_{2}$ thin film was dipped into $\mathrm{Na}_{2} \mathrm{~S}$ methanol solution and rinsed with methanol. These dipped procedures formed one SILAR cycle and was repeated for 6 SILAR cycles. Lastly, dried under ambient air for an hour.

\section{RESULTS AND DISCUSSION}

\section{MORPHOLOGICAL PROPERTIES}

Characterization using FESEM was carried out to study the distribution and size of particles of prepared samples. 
Based on the observation in Figure 1, it looks like CuInS QDs particles were attached to graphene sheet which covered uniformly the whole surface of $\mathrm{TiO}_{2}$ film. From the FESEM images, the average particles size of $\mathrm{TiO}_{2} /$ $\mathrm{rGO} / \mathrm{CuInS} \mathrm{S}_{2}$ increased from \pm 46.52 to $\pm 53.97 \mathrm{~nm}$ in diameter after $\mathrm{Ag}_{2} \mathrm{~S}$ deposition as well as the thickness of the samples which increased from 3.38 to $4.39 \mu \mathrm{m}$. These increments were due to the aggregation of $\mathrm{Ag}_{2} \mathrm{~S}$ particles that formed after the $\mathrm{Ag}_{2} \mathrm{~S}$ deposition as clearly observed in Figure 2. Basically, larger particle size reduced the gap between the particles, hence reduced the internal surface area of the sample.

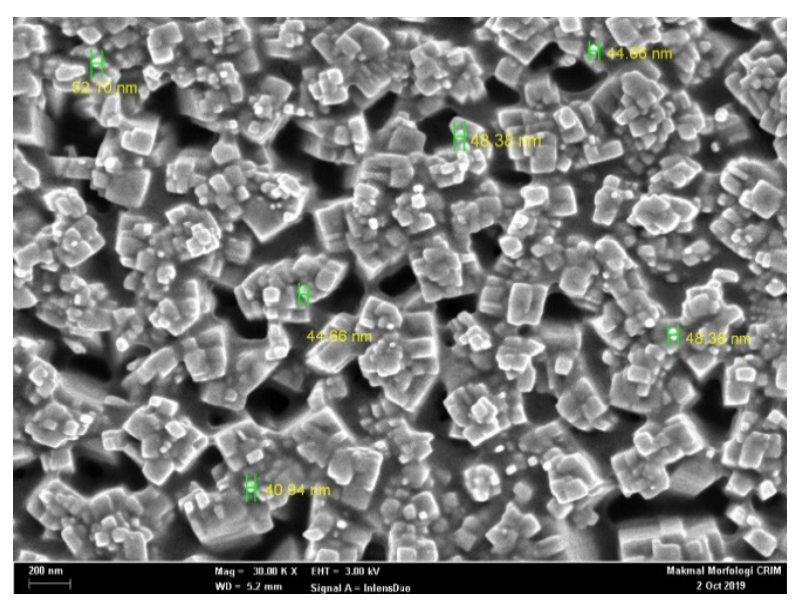

FIGURE 1. Surface morphology of $\mathrm{TiO}_{2} / \mathrm{rGO} / \mathrm{CuInS}_{2}$ thin film

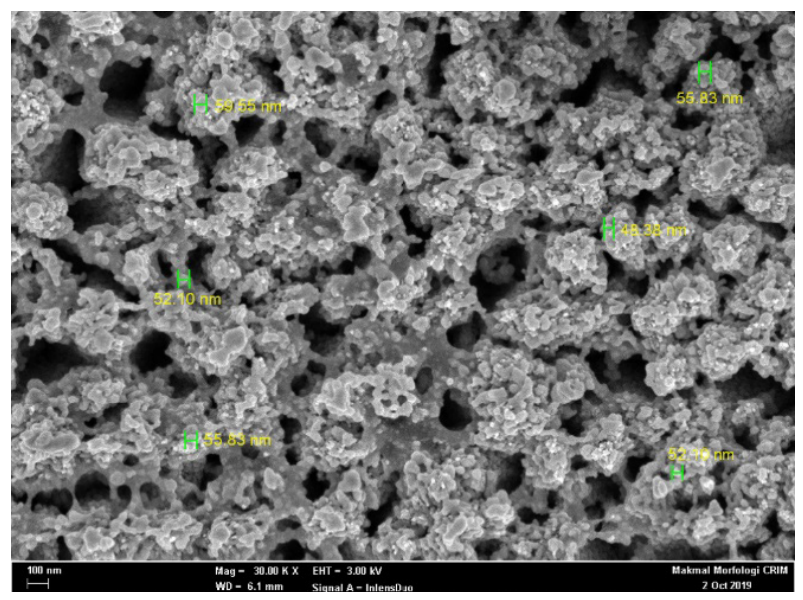

FIGURE 2. Surface morphology of $\mathrm{TiO}_{2} / \mathrm{rGO} / \mathrm{CuInS}_{2}$ thin film with $\mathrm{Ag}_{2} \mathrm{~S}$ deposition layers

Characterization using EDX was performed on $\mathrm{TiO}_{2} /$ $\mathrm{rGO} / \mathrm{CuInS} \mathrm{S}_{2}$ thin film before and after deposition of $\mathrm{Ag}_{2} \mathrm{~S}$ layers to determine the presence of each element in the samples. From the analysis in Figure $3, \mathrm{Cu}, \mathrm{In}$, and $\mathrm{S}$ elements were detected in the spectra which proved that $\mathrm{CuInS}_{2}$ material were successfully deposited on the $\mathrm{TiO}_{2}$ thin film surface. While Figure 4 shows the Ag element which proved that $\mathrm{Ag}_{2} \mathrm{~S}$ layer was successfully applied onto the $\mathrm{TiO}_{2} / \mathrm{rGO} / \mathrm{CuInS}$ thin film. $\mathrm{C}$ element that appeared in both spectra shows the existence of graphene in the samples. 


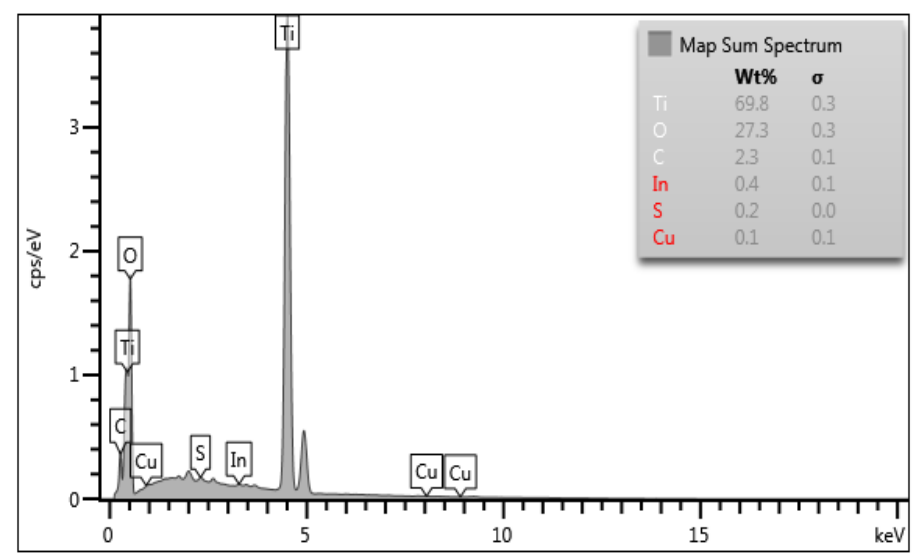

FIGURE 3. EDX spectra of $\mathrm{TiO}_{2} / \mathrm{rGO} / \mathrm{CuInS} \mathrm{S}_{2}$ thin film

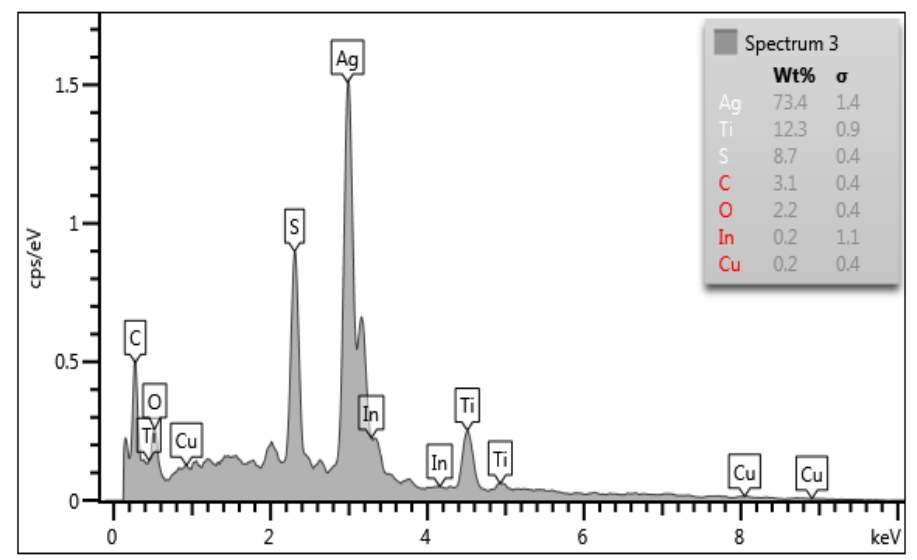

FIGURE 4. EDX spectra of $\mathrm{TiO}_{2} / \mathrm{rGO} / \mathrm{CuInS}_{2}$ thin film with $\mathrm{Ag}_{2} \mathrm{~S}$ deposition layers

AFM characterization was performed to determine the surface roughness of the $\mathrm{TiO}_{2} / \mathrm{rGO} / \mathrm{CuInS}$ thin film with and without the $\mathrm{Ag}_{2} \mathrm{~S}$ coating layer. Based on the AFM images in Figure 5, the RMS value increased after the deposition of $\mathrm{Ag}_{2} \mathrm{~S}$ layers which showed that $\mathrm{Ag}_{2} \mathrm{~S}$ were successfully absorbed and cover the surface of the $\mathrm{TiO}_{2} /$
$\mathrm{rGO} / \mathrm{CuInS} \mathrm{S}_{2}$ thin film. The RMS value of the $\mathrm{TiO}_{2} / \mathrm{rGO} /$ $\mathrm{CuInS}_{2}$ thin film slightly increased from 10.79 to $11.60 \mathrm{~nm}$ with $6 \mathrm{Ag}_{2} \mathrm{~S}$ SILAR cycles (Figure 6). The changes in the RMS value indicated that the presence of $\mathrm{Ag}_{2} \mathrm{~S}$ particles in the sample can be attributed to the increase in particle size of the sample as well.

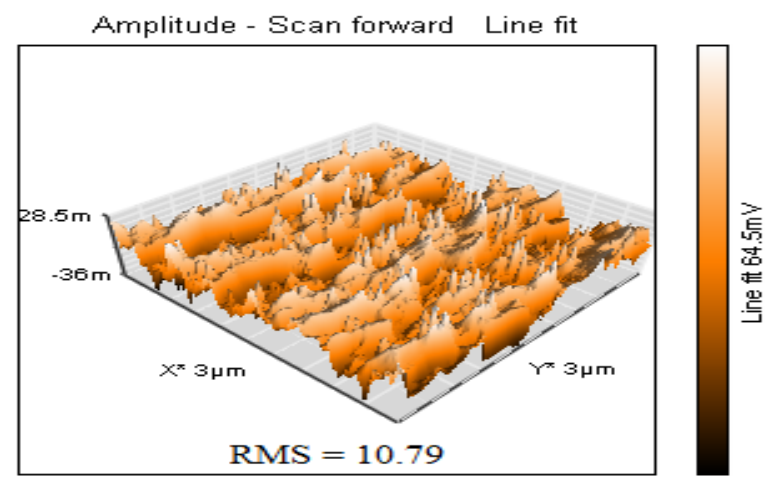

FIGURE 5. Surface roughness of $\mathrm{TiO}_{2} / \mathrm{rGO} / \mathrm{CuInS}$, thin film 


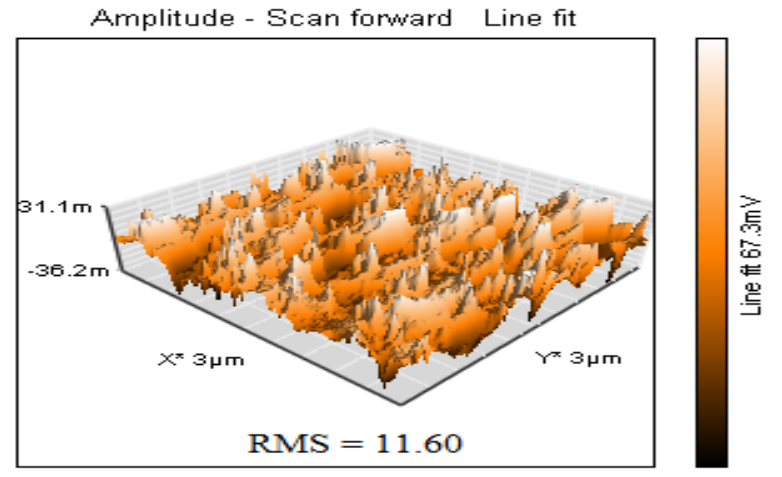

FIGURE 6. Surface roughness of $\mathrm{TiO}_{2} / \mathrm{rGO} / \mathrm{CuInS}_{2} / \mathrm{Ag}_{2} \mathrm{~S}$ thin film

\section{STRUCTURAL PROPERTIES}

XRD characterization was carried out to identify the structure of $\mathrm{TiO}_{2}$, graphene, $\mathrm{CuInS}_{2}$, and $\mathrm{Ag}_{2} \mathrm{~S}$ that could be determined from the crystalline phases of the thin film. The R-labelled peak observed in the XRD spectra refers to $\mathrm{TiO}_{2}$ at angles of $36.08^{\circ}$ corresponding to the plane (101) of the rutile phase (PDF $01-079-5860)$. For rGO, there is peak at $26.35^{\circ}$ corresponding to (002) plane (PDF-01-0898487). As observed in Figure 7, the typical peaks of rGO was not found in spectra. According to Meng et al. (2015), the disappearance of the (002) diffraction peak of rGO indicates the destruction of the regular stacks of graphene sheets by exfoliation or intercalation of reactants.
Other peaks began to appear after $\mathrm{Ag}_{2} \mathrm{~S}$ layers were deposited onto the $\mathrm{TiO}_{2} / \mathrm{rGO} / \mathrm{CuInS}$ thin film. There are $\mathrm{Ag}_{2} \mathrm{~S}$ peaks at angles of $28.97^{\circ}, 31.52^{\circ}, 33.61^{\circ}, 40.74^{\circ}$ and $43.41^{\circ}$ corresponding to planes (111), (-112), (120), (031) and (200) acanthite phases (PDF 00-011-0688). However, the peaks for $\mathrm{CuInS}_{2}$ could not be observed in the XRD spectra. This is because $\mathrm{TiO}_{2}$ and $\mathrm{Ag}_{2} \mathrm{~S}$ produced crystalline peaks while $\mathrm{CuInS}_{2}$ produced amorphous peaks. Basically, the crystalline phase has a higher and narrower intensity peak. On the other hand, the amorphous phase has a lower and wider peak intensity. Different peaks in the same spectra cause the amorphous peaks to be less prominent compared to the crystalline peaks. Additionally, there are other peaks present in the spectra that may refer to the FTO glass itself.

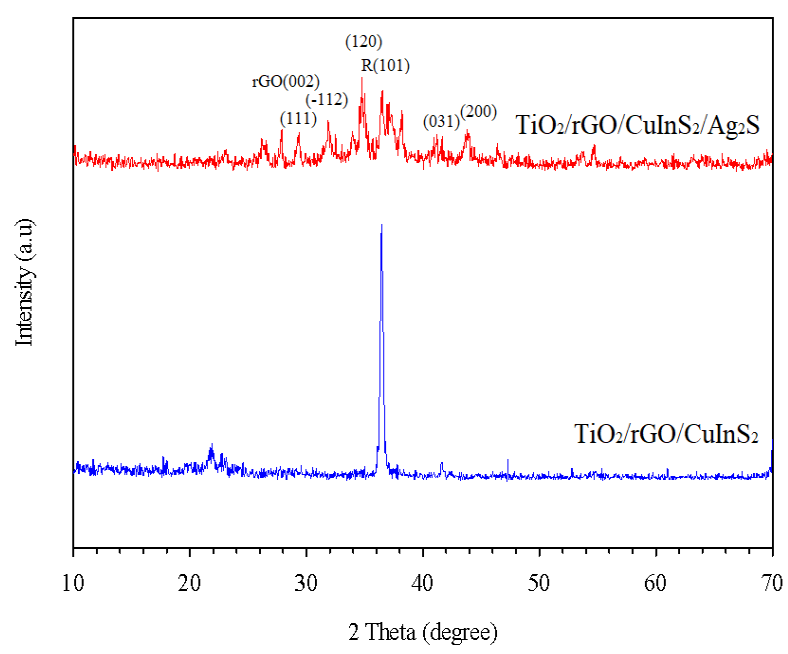

FIGURE 7. XRD spectra of $\mathrm{TiO}_{2} / \mathrm{rGO} / \mathrm{CuInS}_{2}$ thin film with $\mathrm{Ag}_{2} \mathrm{~S}$ deposition layers 
The crystallite size of $\mathrm{TiO}_{2}$ and $\mathrm{Ag}_{2} \mathrm{~S}$ in $\mathrm{TiO}_{2} / \mathrm{rGO} /$ $\mathrm{CuInS}_{2}$ was estimated by Scherrer formula (1). From the calculation, $k$ is the shape constant (0.9), $\lambda$ is the wavelength of the X-ray $(0.15406 \mathrm{~nm}), \beta$ is the FWHM in radians and $\theta$ is the Bragg's angle in degree. As stated in
Table 1, the crystallite size of $\mathrm{TiO}_{2}$ was around \pm 33.19 $\mathrm{nm}$ to $\pm 33.97 \mathrm{~nm}$ for both samples. While, the crystallite size of $\mathrm{Ag}_{2} \mathrm{~S}$ in $\mathrm{TiO}_{2} / \mathrm{rGO} / \mathrm{CuInS}_{2}$ was estimated to be around $\pm 19.26 \mathrm{~nm}$.

$$
d=\frac{k \lambda}{\beta \cos \theta}
$$

TABLE 1. Crystallite size of $\mathrm{TiO}_{2}$ and $\mathrm{Ag}_{2} \mathrm{~S}$ using Scherrer equation

\begin{tabular}{lcclc}
\hline & $2 \theta$ position & FWHM & \multicolumn{2}{c}{ Crystallite size } \\
\multicolumn{1}{c}{ Sample } & $($ deg. $)$ & $($ deg. $)$ & $(0.01 \mathrm{~nm})$ & \\
\hline Without $\mathrm{Ag}_{2} \mathrm{~S}$ & $\mathrm{TiO}_{2}$ & 36.08 & 0.28 & 33.19 \\
With $\mathrm{Ag}_{2} \mathrm{~S}$ & $\mathrm{TiO}_{2}$ & 36.05 & 0.27 & 33.97 \\
& $\mathrm{Ag}_{2} \mathrm{~S}$ & 31.52 & 0.48 & 19.26 \\
\hline
\end{tabular}

\section{OPTICAL PROPERTIES}

The optical spectrum of the thin film $\mathrm{TiO}_{2} / \mathrm{rGO} / \mathrm{CuInS} \mathrm{S}_{2}$ with and without $\mathrm{Ag}_{2} \mathrm{~S}$ deposition layers can be observed through UV-VIS Spectroscopy as shown in Figure 8. The significant changes in light absorption can be compared where the absorption of visible light much higher by the QDs structure with the presence of the $\mathrm{Ag}_{2} \mathrm{~S}$ deposition layer. As the light is absorbed by photosensitizer, the result is an increase in the energy content of the QDs structures. A blue-shift was observed in the electronic properties of the QDs $\mathrm{CuInS}$, with the $\mathrm{Ag}_{2} \mathrm{~S}$ presence. Even though a blue-shift has been typically observed in the literature for shelling of chalcopyrite $\mathrm{CuInS}_{2}$ (Meng et al. 2015), and it results from the compounding on the surface between the QDs material and the $\mathrm{Ag}_{2} \mathrm{~S}$. Furthermore, a blue-shift can be attributed to the larger particle size of the compound as the $\mathrm{Ag}_{2} \mathrm{~S}$ layer was deposited. In the meantime, a small red-shift in the absorption region was also detected at the visible edge from the UV-VIS spectra. In this process, the compound formed has a new band gap energy representative of the ratio of the component materials. However, further studies need to be conducted to identify the materials band gap since the current analysis can only be done up to $700 \mathrm{~nm}$ wavelength. Supposedly, the particle size can also be the aspect affecting the band gap of the substantial itself. Therefore, the band gap of $\mathrm{TiO}_{2} / \mathrm{rGO} / \mathrm{CuInS}$ thin film with $\mathrm{Ag}_{2} \mathrm{~S}$ layers supposed to be narrower than before the $\mathrm{Ag}_{2} \mathrm{~S}$ deposition.

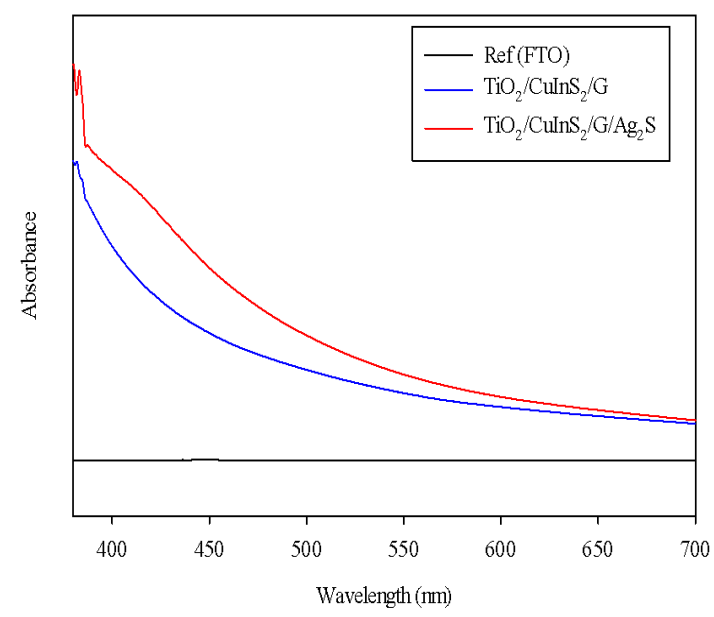

FIGURE 8. UV-VIS spectra of $\mathrm{TiO}_{2} / \mathrm{rGO} / \mathrm{CuInS}$ thin film with $\mathrm{Ag}_{2} \mathrm{~S}$ deposition layers 


\section{ELECTRICAL PROPERTIES}

Figure 9 shows the semi-circular curves of electrochemical impedance spectra (EIS) that show the interfacial chargetransfer resistances of the cells. The $R_{s}$ of the electrodes in both samples is in the range of $53.3-52.1 \Omega$ since both samples used identical FTO substrate, $\mathrm{TiO}_{2}$ films, and electrolyte. This shows that passivation layer has no effect to the interface combination between FTO substrate and $\mathrm{TiO}_{2}$ films (Peng et al. 2014).

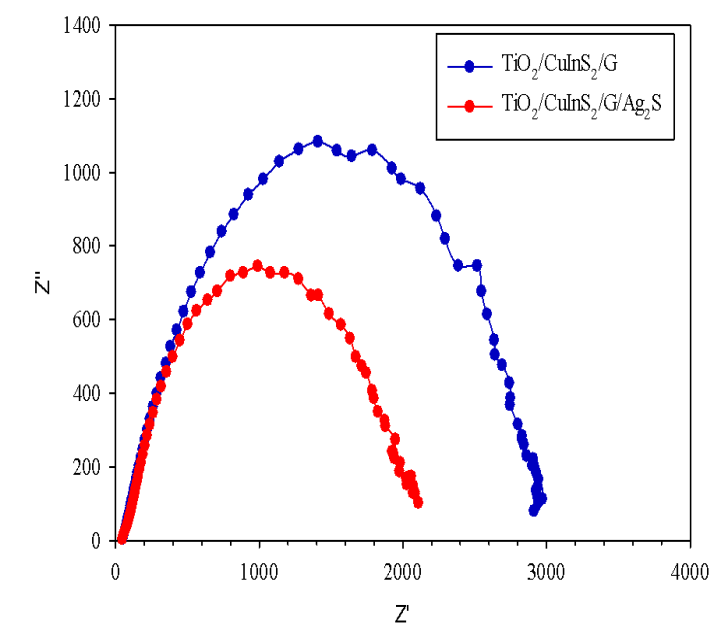

FIGURE 9. EIS spectra of $\mathrm{TiO}_{2} / \mathrm{rGO} / \mathrm{CuInS}_{2}$ thin film with $\mathrm{Ag}_{2} \mathrm{~S}$ deposition layers

However, decrement of semi-circular diameter was observed with the presence of $\mathrm{Ag}_{2} \mathrm{~S}$ layer. The changes should be ascribed to the charge transfer between $\mathrm{TiO}_{2} /$ QDs interface and/or QDs/electrolyte interface. From the EIS spectra, it indicates that the charge transfers resistance decreases with passivation deposition layer (Solaiyammal \& Murugakoothan 2019). The lifetime of the electrons, $\tau_{e}=1 /\left(2 \pi f_{\max }\right)$ where $f_{\max }$ is the maximum frequency of the peaks (Tian et al. 2012). The electron lifetime increases with size of the particles as stated in Table 2. According to Ilaiyaraja et al. (2018), due to larger surface defects in smaller sized particles, the electron lifetime might get influenced as well.

TABLE 2. EIS parameters of $\mathrm{rGO} / \mathrm{CuInS}_{2}$ QDs solar cells

\begin{tabular}{rccc}
\hline Sample & $R_{\mathrm{S}}(\Omega)$ & $R_{\mathrm{CT}}(\mathrm{k} \Omega)$ & $\mathrm{e}(\mathrm{ms})$ \\
\hline Without $\mathrm{Ag}_{2} \mathrm{~S}$ & 53.3 & 3.03 & 1.77 \\
With $\mathrm{Ag}_{2} \mathrm{~S}$ & 52.1 & 2.14 & 3.43 \\
\hline
\end{tabular}

Differences in solar cell structure and material will certainly show different performance. Therefore, it is very significant to compare the value of power conversion efficiency for each sample through the I-V curve. In this study, the solar cells comprised redox couple $\mathrm{I}_{-} \mathrm{I}_{3}{ }^{-}$as the electrolyte and Pt glass as the counter electrode with different photo anodes. The I-V curve was measured under simulated sunlight with active area of $0.25 \mathrm{~cm}^{2}$. The performance of the solar cells $\left(V_{o c}, I_{s c}, P_{\max }, \eta\right)$ for both samples were specified in detail in Table 3 . The efficiency values of the samples studied can be compared and discussed. 
TABLE 3. Photovoltaic parameters of the assembled $\mathrm{TiO}_{2} / \mathrm{rGO} / \mathrm{CuInS}_{2}$ and $\mathrm{TiO}_{2} / \mathrm{rGO} / \mathrm{CuInS}_{2} / \mathrm{Ag}_{2} \mathrm{~S}$ solar cells

\begin{tabular}{lcccc}
\hline \multicolumn{1}{c}{ Sample } & $V_{\mathrm{OC}}(\mathrm{V})$ & $J_{\mathrm{SC}}\left(\mathrm{mA} \mathrm{cm}^{-2}\right)$ & $F F$ & $\eta(\%)$ \\
\hline Without $\mathrm{Ag}_{2} \mathrm{~S}$ & 0.376 & 0.356 & 0.55 & 0.074 \\
With $\mathrm{Ag}_{2} \mathrm{~S}$ & 0.410 & 1.676 & 0.48 & 0.330 \\
\hline
\end{tabular}

As expected, the presence of the $\mathrm{Ag}_{2} \mathrm{~S}$ layer helps in enhance the efficiency of photovoltaic power conversion. From the I-V curve as shown in Figure 10, obvious increment observed for $\mathrm{TiO}_{2} / \mathrm{rGO} / \mathrm{CuInS}$, photo anode with $\mathrm{Ag}_{2} \mathrm{~S}$ layers compared to the other sample. Compared to $\mathrm{TiO}_{2} / \mathrm{rGO} / \mathrm{CuInS}_{2}$, photo anode with $\mathrm{Ag}_{2} \mathrm{~S}$ deposition layers produced higher value of power conversion efficiency, $0.33 \%$ with higher value of $I$ and $F F, 0.419 \mathrm{~mA}$ and $48 \%$, respectively. It proved that $\mathrm{TiO}_{2} / \mathrm{rGO} / \mathrm{CuInS}_{2} /$ $\mathrm{Ag}_{2} \mathrm{~S}$ have better capability in electrical conductivity and electron mobility than $\mathrm{TiO}_{2} / \mathrm{rGO} / \mathrm{CuInS}_{2}$. As the result, solar cell performance improved with the presence of the $\mathrm{Ag}_{2} \mathrm{~S}$ deposition layers compared to the sample without the $\mathrm{Ag}_{2} \mathrm{~S}$ passivation layers.

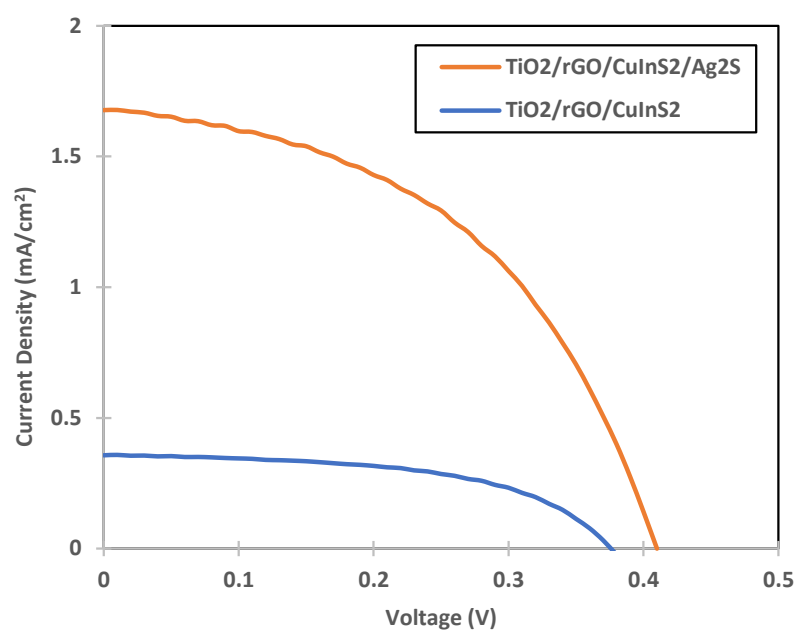

FIGURE $10 . J-V$ curve of $\mathrm{TiO}_{2} / \mathrm{rGO} / \mathrm{CuInS}_{2}$ thin film with and without $\mathrm{Ag}_{2} \mathrm{~S}$ deposition layers

\section{CONCLUSION}

$\mathrm{Ag}_{2} \mathrm{~S}$ layers has been successfully deposited onto $\mathrm{TiO}_{2} /$ $\mathrm{rGO} / \mathrm{CuInS}$, thin film using SILAR technique. The effect of $\mathrm{Ag}_{2} \mathrm{~S}$ on the photovoltaic performance of $\mathrm{rGO} / \mathrm{CuInS}_{2}$ based QDSSCs was investigated. From FESEM images, the average particles size of the samples ranged from \pm 46.52 to $\pm 53.97 \mathrm{~nm}$ in diameter. The XRD results showed peaks at $33.61^{\circ}, 40.74^{\circ}$ and $43.41^{\circ}$ of $\mathrm{Ag}_{2} \mathrm{~S}$ structure and the crystallite size of $\mathrm{Ag}_{2} \mathrm{~S}$ was estimated around $\pm 19.26 \mathrm{~nm}$. According to UV-VIS analysis, $\mathrm{TiO}_{2} / \mathrm{rGO} /$
$\mathrm{CuInS}_{2}$ showed better light absorption capability with the presence of $\mathrm{Ag}_{2} \mathrm{~S}$ layers. Regarding the considerable results obtained, it was pointed out that $\mathrm{TiO}_{2} / \mathrm{rGO} / \mathrm{CuInS}_{2}$ with $\mathrm{Ag}_{2} \mathrm{~S}$ as passivation layer can be introduced as an effective photo anode for making efficient QDSSCs devices with $0.33 \%$ of power conversion efficiency. Therefore, for further investigation, other characterizations should be carried out in order to prove the influence of $\mathrm{Ag}_{2} \mathrm{~S}$ layers in enhancement of the $\mathrm{rGO} / \mathrm{CuInS}_{2}$ based QDSSCs performance. 


\section{ACKNOWLEDGEMENTS}

The authors would like to acknowledge the financial assistance provided (Grant No.: 07-01-02-SF1388) by the Ministry of Energy, Science, Technology, Environment and Climate Change (MESTECC). Besides, the authors are thankful to the supports received from Solar Energy Research Institute (SERI) and Center for Research and Instrumentation Management (CRIM), Universiti Kebangsaan Malaysia (UKM).

\section{REFERENCES}

Han, M., Jia, J., Yu, L. \& Yi, G. 2015. Fabrication and photoelectrochemical characteristics of $\mathrm{CuInS}_{2}$ and $\mathrm{PbS}$ quantum dot co-sensitized $\mathrm{TiO}_{2}$ nanorod photoelectrodes. RSC Advances 5(64): 51493-51500.

Holi, A.M., Zainal, Z., Talib, Z.A., Lim, H.N., Yap, C.C., Chang, S.K. \& Ayal, A.K. 2017. Enhanced photoelectrochemical performance of $\mathrm{ZnO}$ nanorod arrays decorated with $\mathrm{CdS}$ shell and Ag2S quantum dots. Superlattices and Microstructures 103(2017): 295-303.

Hosseinpour-Mashkani, S.M., Salavati-Niasari, M. \& Mohandes, F. 2014. CuInS ${ }_{2}$ nanostructures: Synthesis, characterization, formation mechanism and solar cell applications. Journal of Industrial and Engineering Chemistry 20(5): 3800-3807.

Ilaiyaraja, P., Rakesh, B., Das, T.K., Mocherla, P.S. \& Sudakar, C. 2018. CuInS 2 quantum dot sensitized solar cells with high $\mathrm{VOC} \approx 0.9 \mathrm{~V}$ achieved using microsphere-nanoparticulate $\mathrm{TiO}_{2}$ composite photoanode. Solar Energy Materials and Solar Cells 178: 208-222.

Kouhnavard, M., Ikeda, S., Ludin, N.A., Khairudin, N.A., Ghaffari, B.V., Mat-Teridi, M.A., Ibrahim, M.A., Sepeai, S. \& Sopian, K. 2014. A review of semiconductor materials as sensitizers for quantum dot-sensitized solar cells. Renewable and Sustainable Energy Reviews 37(2014): 397-407.

Kumari, A., Singh, I., Prasad, N., Dixit, S.K., Rao, P.K., Bhatnagar, P.K., Mathur, P.C., Bhatia, C.S. \& Nagpal, S. 2014. Improving the efficiency of a poly(3-hexylthiophene)$\mathrm{CuInS}_{2}$ photovoltaic device by incorporating graphene nanopowder. Journal of Nanophotonics 8 (1): 083092.

Madhavan, A.A., Kalluri, S., Chacko, D.K., Arun, T.A., Nagarajan, S., Subramanian, K.R., Nair, A.S., Nair, S.V. \& Balakrishnan, A. 2012. Electrical and optical properties of electrospun $\mathrm{TiO}_{2}$-graphene composite nanofibers and its application as DSSC photo-anodes. RSC Advances 2(33): 13032-13037.

Meng, W., Zhou, X., Qiu, Z., Liu, C., Chen, J. \& Yue, W. 2015. Reduced graphene oxide-supported aggregates of $\mathrm{CuInS}_{2}$ quantum dots as an effective hybrid electron acceptor for polymer-based solar cells. Carbon 96: 532-540.

Mustakim, N.S.M., Ubani, C.A., Sepeai, S., Ludin, N.A., Teridi, M.A.M. \& Ibrahim, M.A. 2018. Quantum dots processed by SILAR for solar cell applications. Solar Energy 163(2018): 256-270
Peng, Z., Liu, Y., Zhao, Y., Chen, K., Cheng, Y., Kovalev, V. \& Chen, W. 2014. ZnSe passivation layer for the efficiency enhancement of $\mathrm{CuInS}_{2}$ quantum dots sensitized solar cells. Journal of Alloys and Compounds 587(2014): 613-617.

Solaiyammal, T. \& Murugakoothan, P. 2019. Green synthesis of $\mathrm{Au}$ and the impact of $\mathrm{Au}$ on the efficiency of $\mathrm{TiO}_{2}$ based dye sensitized solar cell. Materials Science for Energy Technologies 2(2): 171-180.

Tian, J., Gao, R., Zhang, Q., Zhang, S., Li, Y., Lan, J., Qu, X. \& Cao, G. 2012. Enhanced performance of CdS/CdSe quantum dot cosensitized solar cells via homogeneous distribution of quantum dots in $\mathrm{TiO}_{2}$ film. The Journal of Physical Chemistry C 116(35): 18655-18662.

Tubtimtae, A., Wu, K.L., Tung, H.Y., Lee, M.W. \& Wang, G.J. 2010. $\mathrm{Ag}_{2} \mathrm{~S}$ quantum dot-sensitized solar cells. Electrochemistry Communications 12(9): 1158-1160.

Ubani, C.A., Ibrahim, M.A., Teridi, M.A.M., Sopian, K., Ali, J. \& Chaudhary, K.T. 2016. Application of graphene in dye and quantum dots sensitized solar cell. Solar Energy 137: 531-550.

Yue, W., Lan, M., Zhang, G., Sun, W., Wang, S. \& Nie, G. 2014. Size-dependent polymer/CuInS $\mathrm{S}_{2}$ solar cells with tunable synthesis of $\mathrm{CuInS}_{2}$ quantum dots. Materials Science in Semiconductor Processing 24(2014): 117-125.

Zhang, R., Qi, S., Jia, J., Torre, B., Zeng, H., Wu, H. \& Xu, X. 2015a. Size and refinement edge-shape effects of graphene quantum dots on UV-visible absorption. Journal of Alloys and Compounds 623(2015): 186-191.

Zhang, X., Liu, J., Zhang, J., Vlachopoulos, N. \& Johansson, E.M. 2015b.ZnO@ $\mathrm{Ag}_{2} \mathrm{~S}$ core-shell nanowire arrays for environmentally friendly solid-state quantum dot-sensitized solar cells with panchromatic light capture and enhanced electron collection. Physical Chemistry Chemical Physics 17(19): 12786-12795.

Nurul Syafiqah Mohamed Mustakim

Spectrum International College of Technology

2F-26A, The Main Place Mall

Jalan USJ21/10, USJ 21

47360 Subang Jaya, Selangor Darul Ehsan

Malaysia

Nurul Syafiqah Mohamed Mustakim, Muhazri Abd Mutalib, Suhaila Sepeai, Norasikin Ahmad Ludin, Mohd Asri Mat Teridi $\&$ Mohd Adib Ibrahim*

Solar Energy Research Institute (SERI)

Universiti Kebangsaan Malaysia

43600 UKM Bangi, Selangor Darul Ehsan

Malaysia

*Corresponding author; email: mdadib@ukm.edu.my

Received: 12 August 2020

Accepted: 27 August 2020 